\title{
Childhood Cancer and Traffic-Related Air Pollution Exposure in Pregnancy and Early Life
}

\author{
Julia E. Heck, ${ }^{1}$ Jun Wu, ${ }^{2}$ Christina Lombardi, ${ }^{1}$ Jiaheng Qiu, ${ }^{3}$ Travis J. Meyers, ${ }^{1}$ Michelle Wilhelm, ${ }^{1}$ \\ Myles Cockburn, ${ }^{4}$ and Beate Ritz ${ }^{1}$
}

${ }^{1}$ Department of Epidemiology, School of Public Health, University of California, Los Angeles, Los Angeles, California, USA; ${ }^{2}$ Program in Public Health and Department of Epidemiology, University of California, Irvine, Irvine, California, USA; ${ }^{3}$ Department of Biostatistics, School of Public Health, University of California, Los Angeles, Los Angeles, California, USA; ${ }^{4}$ Department of Preventive Medicine, Keck School of Medicine, University of Southern California, Los Angeles, California, USA

BACKGROUND: The literature on traffic-related air pollution and childhood cancers is inconclusive, and little is known on rarer cancer types.

OвJECTIVEs: We sought to examine associations between childhood cancers and traffic-related pollution exposure.

Methods: The present study included children $<6$ years of age identified in the California Cancer Registry (born 1998-2007) who could be linked to a California birth certificate $(n=3,590)$. Controls were selected at random from California birthrolls $(n=80,224)$. CAlifornia LINE Source Dispersion Modeling, version 4 (CALINE4) was used to generate estimates of local traffic exposures for each trimester of pregnancy and in the first year of life at the address indicated on the birth certificate. We checked our findings by additionally examining associations with particulate matter $\left(\leq 2.5 \mu \mathrm{m}\right.$ in aerodynamic diameter; $\mathrm{PM}_{2.5}$ ) pollution measured by community-based air pollution monitors, and with a simple measure of traffic density.

RESULTS: With unconditional logistic regression, a per interquartile range increase in exposure to traffic-related pollution during the first trimester $(0.0538 \mathrm{ppm}$ carbon monoxide, estimated using CALINE4) was associated with acute lymphoblastic leukemia [ALL; first trimester odds ratio $(\mathrm{OR})=1.05$; 95\% CI: 1.01, 1.10]; germ cell tumors $(\mathrm{OR}=1.16$; 95\% CI: 1.04, 1.29), particularly teratomas $(\mathrm{OR}=1.26 ; 95 \% \mathrm{CI}: 1.12,1.41)$; and retinoblastoma $(\mathrm{OR}=1.11 ; 95 \% \mathrm{CI}: 1.01,1.21)$, particularly bilateral retinoblastoma $(\mathrm{OR}=1.16$; 95\% CI: $1.02,1.33)$. Retinoblastoma was also associated with average $\mathrm{PM}_{2.5}$ concentrations during pregnancy, and ALL and teratomas were associated with traffic density near the child's residence at birth.

ConClusions: We estimated weak associations between early exposure to traffic pollution and several childhood cancers. Because this is the first study to report on traffic pollution in relation to retinoblastoma or germ cell tumors, and both cancers are rare, these findings require replication in other studies.

Citation: Heck JE, Wu J, Lombardi C, Qiu J, Meyers TJ, Wilhelm M, Cockburn M, Ritz B. 2013. Childhood cancer and traffic-related air pollution exposure in pregnancy and early life. Environ Health Perspect 121:1385-1391; http://dx.doi.org/10.1289/ehp.1306761

\section{Introduction}

Motor vehicle emissions are a major source of ambient air pollution in the United States and elsewhere. In a recent meeting, the International Agency for Research on Cancer (IARC) classified diesel exhaust as carcinogenic and gasoline exhaust as possibly carcinogenic to humans (Benbrahim-Tallaa et al. 2012). Traffic exhaust contains carbon monoxide, nitrogen oxides, and toxic air contaminants such as benzene, formaldehyde, 1,3-butadiene, and nitroarenes. Particulate components of traffic exhaust include metals, elemental carbon, organic carbon, and sulphate. A number of these components have been classified as established or suspected carcinogens in occupational settings (IARC 2012).

The literature on traffic-related air pollution and childhood cancers has been equivocal, likely for several reasons, including variation in exposure assessment methods and time periods of exposure. In addition, because of small numbers of cases, disparate cancer types were grouped as a single outcome. Many studies have used simple proxy measures of exposure such as rates of neighborhood car ownership, gas station density, or residential proximity to roads, gas stations, or car repair shops (Abdul Rahman et al. 2008; Alexander et al. 1996; Brosselin et al. 2009; Harrison et al. 1999; Nordlinder and Jarvholm 1997; Reynolds et al. 2002; Steffen et al. 2004; Weng et al. 2009). Other studies have classified exposure based on traffic density (Harrison et al. 1999; Langholz et al. 2002; Pearson et al. 2000; Reynolds et al. 2001, 2002, 2004; Savitz and Feingold 1989; Visser et al. 2004; Von Behren et al. 2008). Only a few studies have classified exposure based on measurements of air pollutants from air monitors (Amigou et al. 2011; Weng et al. 2008) or sophisticated air pollution modeling strategies that consider more factors that influence exhaust levels such as chemical reactions of pollutants, background pollution levels, land use, or weather (Crosignani et al. 2004; Feychting et al. 1998; Raaschou-Nielsen et al. 2001; Vinceti et al. 2012). In a previous study that compared different ways of measuring traffic-related air pollution exposures in relation to birth outcomes, Wu et al. (2011) showed that traffic density yields lower effect estimates than those generated in more complex models.

The literature is also limited in scope because most studies have reported only on leukemias, central nervous system (CNS) tumors, or all childhood cancer types combined, and few have had sufficient sample sizes to stratify by cancer subtypes or estimate associations with rarer tumors. Further, most studies assessed exposure using the child's address at the time of diagnosis, study entry, or death, and are therefore best interpreted as estimating associations with traffic exposure during childhood. Because the pathogenesis of at least some childhood cancers is likely to begin in utero, these studies may not capture an important exposure period for early childhood cancers (Greaves and Wiemels 2003; Lafiura et al. 2007).

We a priori hypothesized that because of the fetus's greater vulnerability to environmental toxins, exposures during the pregnancy period would be most relevant for childhood cancer risk (Selevan et al. 2000). To our knowledge, six studies have examined associations between childhood cancers and exposures during pregnancy. Two reported that living near gas stations or auto repair garages was associated with acute lymphoblastic leukemia (ALL) and acute myeloid leukemia (AML) (Brosselin et al. 2009) or with all leukemias combined (Steffen et al. 2004). Of studies that evaluated traffic density near the child's residence, two reported

Address correspondence to J. Heck, Department of Epidemiology, Box 951772, 650 Charles E. Young Dr., Los Angeles, CA 90095-1772 USA. Telephone: (310) 825-8579. E-mail: jeheck@ucla.edu

We thank A. Park for his assistance with the manuscript.

This study was supported by grants from the National Institute of Environmental Health Sciences (R21ES018960, R21ES019986, P30ES007048) and the National Cancer Institute (R25CA087949).

The authors declare they have no actual or potential competing financial interests.

Received: 5 March 2013; Accepted: 9 September 2013; Advance Publication: 10 September 2013; Final Publication: 1 December 2013. 
no association with leukemias (Reynolds et al. 2001, 2004), and a third reported no association with ALL specifically (Von Behren et al. 2008). However, traffic density was associated with CNS tumors in the Reynolds et al. (2004) study. One study that used Operational Street Pollution Modelling, which examined children who were diagnosed up through 15 years of age, found no associations between traffic pollution and leukemias, CNS tumors, or lymphomas, except that associations were observed between Hodgkin lymphoma and both benzene and modeled nitrogen dioxide $\left(\mathrm{NO}_{2}\right)$ as a marker of traffic, modeled as continuous variables (RaaschouNielsen et al. 2001).

The purpose of the present study was to estimate associations between common childhood cancers and traffic-related air pollution exposure during pregnancy and early childhood ( $<1$ year of age).

\section{Methods}

In the present investigation we identified incident cases of cancers from the California Cancer Registry diagnosed 1998-2007 (born 1998-2007) (Heck et al. 2013a). Because our main interest was exposures occurring in pregnancy and early life, we included only cases $\leq 5$ years of age at the time of cancer diagnosis. We used a probabilistic linkage program (LinkPlus; CDC, Atlanta, GA) to match each registry case with his or her birth certificate by first and last names, dates of birth, and (when available) social security number; we were able to match $89 \%$ of cases to a California birth certificate. Controls, frequency-matched by year of birth (20:1 matching rate), were randomly selected from California birth rolls. Controls had no record of a cancer diagnosis in California before 6 years of age. Because this was a noncontact study, it was deemed exempt from informed consent requirements. All information was taken from Cancer Registry records, birth certificates, or year 2000 Census data. Strict provisions were made to maintain the confidentiality of participants. The study received approvals from the human subjects protection boards of the University of California, Los Angeles; the University of California, Irvine; and the California Health and Human Services Agency.

At all time points, air pollution exposure was estimated based upon each child's address as listed on the birth certificate. Addresses were automatically geocoded using our opensource geocoder with a manual resolution process for unmatched addresses (Goldberg et al. 2008). Resulting locations were recorded along with the relevant date of birth and gestational age information, as taken from the birth certificate. When gestational ages were improbably long ( $>45$ weeks), they were classified as missing. We defined the first trimester as weeks $1-13$ of pregnancy, the second trimester as weeks 14-26 of pregnancy, and the third trimester as week 27 to birth.

The present study included only children for whom there was parcel-level or street-level geocoding and who listed a home address within California ( $n=84,268)$. Of these, four children were excluded because their addresses were located on the islands off the Los Angeles coast with no roadway data available. We report on cancer subtypes for which there were at least 65 cases, as classified by SEER (Surveillance, Epidemiology, and End Results) recode of International Classification of Childhood Cancer, 3rd Edition (ICCC-3; Steliarova-Foucher et al. 2005). The final analysis included 3,590 cases [1,280 cases of ALL (SEER code 011), 229 AML (code 012), 78 non-Hodgkin lymphomas (NHL; code 022-023), 125 ependymomas (code 031), 282 astrocytomas (code 032), 205 intracranial and intraspinal embryonal tumors (code 033), 99 medulloblastomas [International Classification of Diseases for Oncology, 3rd Edition (ICD-O) (Fritz 2000) codes 9470-9472, 9474, 9480], 65 primitive neuroectodermal tumors (PNET; ICD-O-3 code 9473), 417 neuroblastomas (code 041), 254 retinoblastomas (code 050; 165 unilateral, 87 bilateral, and 2 with laterality unknown), 298 Wilms tumors (code 061), 127 hepatoblastomas (code 071), 144 rhabdomyosarcomas (code 091), 140 germ cell tumors [codes 101-105; including 72 teratomas (ICD-O-3 code 9080), 49 yolk sac tumors (ICD-O-3 code 9071), and 19 of other histologic types], and 80,224 controls.

CAlifornia LINE Source Dispersion Model, version 4 (CALINE4) is a Gaussian dispersion model used to quantify exposure to traffic pollutants at a given address. Previous studies have found moderate to high correlations ( $r=0.55-0.95)$ of CALINE4modeled estimates with measured variability of traffic-related air pollutants (Benson 1989, 1992; Broderick et al. 2005; Gauderman et al. 2005; Levitin et al. 2005). Model inputs were based on local traffic emissions of both gasoline vehicles and diesel trucks within a 1,500-m buffer around an address, and included traffic volumes, roadway geometry, vehicle emission rates, and meteorology. We selected the 1,500-m buffer because previous studies showed narrow impact zones of primary traffic emissions, ranging from $300 \mathrm{~m}$ (Zhu et al. 2002) to up to 2,600 m (Hu et al. 2009). The California Department of Transportation (Caltrans) provided information on annual average daily traffic counts on freeways, highways, and "major surface streets," as defined by Caltrans. Annual average daily truck traffic counts on freeways and highways were also obtained from Caltrans. Emission factors for carbon monoxide (CO), nitrogen oxides $\left(\mathrm{NO}_{\mathrm{x}}\right)$, and particulate matter with aerodynamic diameter $\leq 2.5 \mu \mathrm{m}\left(\mathrm{PM}_{2.5}\right)$ were obtained by county, year, and season (winter and summer) from the California Air Resources Board (CARB)'s emission factors (EMFAC2007) vehicle emissions model (CARB 2007). Hourly wind speed, direction, and temperature data were obtained from the CARB Air Quality and Meteorological Information System (CARB 2010). Our validation of the CALINE4 model showed a high correlation $(r=0.87)$ of CALINE4modeled monthly $\mathrm{NO}_{\mathrm{x}}$ concentrations with measurements at nine monitoring sites in the Long Beach study area in 2007 and 2008 (unpublished data).

CALINE4 modeling produces average estimates of local long-term exposure to CO, $\mathrm{NO}_{\mathrm{x}}$, and $\mathrm{PM}_{2.5}$. These pollutants should be considered as markers for the traffic-related pollution mix rather than as carcinogens in and of themselves. Values were computed for each of the four time periods of interest (first through third trimesters and first year of life). Because correlations between modeled $\mathrm{CO}$ and $\mathrm{NO}_{\mathrm{x}}(r-0.98-0.99)$ and between $\mathrm{PM}_{2.5}$ and both $\mathrm{CO}$ and $\mathrm{NO}_{\mathrm{x}}(r-0.90-0.93)$ were very high, we report results only for modeled CO.

Numbers of children included in analyses varied according to the time period examined. Children born before the third trimester were excluded from analyses of exposures during the third trimester, along with 4,961 children (217 cases, 4,744 controls) with missing information on gestational age. Children who died during their first year of life (485 cases, 467 controls) were excluded from analyses of exposures during the first year. In addition, if meteorological values were missing for more than $25 \%$ of days during any time period for a given child, the child was excluded from the analysis of that time period $(1.7-3.6 \%$ of participants across the four time periods).

Associations between air pollution and childhood cancers were estimated using separate unconditional logistic regression models (SAS Institute Inc., Cary, NC) for each outcome, using the same group of 80,224 controls in each regression. We estimated increases in odds of each cancer per interquartile range (IQR) increase in CO. We adjusted for potential confounders using data acquired from birth certificates and year 2000 census information. Confounding variables included in multivariate models were the child's year of birth, mother's and father's race/ethnicity [non-Hispanic white, non-Hispanic black, Hispanic (any race), or other/not specified], mother's education $(\leq 8,9-<12,12$, $13-15$, or $\geq 16$ years), mother's country of birth (United States, Mexico, or other), parity $(0,1, \geq 2)$, method of payment for prenatal care (private insurance vs. other payment methods, including self-pay and government 
programs), and neighborhood socioeconomic index. Both race/ethnicity and socioeconomic status are related to traffic pollution exposure in California (Houston et al. 2004). Neighborhood socioeconomic index was derived using principal components analysis to create a single, five-level socioeconomic status measure from seven census tract-level indicators of socioeconomic status (education, median household income, percent living 200\% below poverty, percent blue-collar workers, percent older than 16 years without employment, median rent, and median house value) (Yost et al. 2001). We have previously shown that method of payment for prenatal care is a reasonable proxy for family income (Ritz et al. 2007). Parity (Dockerty et al. 2001; Schuz et al. 1999; Shu et al. 1995) and mother's country of birth (Heck et al. 2012; Johnson et al. 2008; Von Behren and Reynolds 2003) have previously been reported to be associated with childhood cancers. We considered adjustment for maternal age and paternal years of education, but because their inclusion in models did not change effect estimates by $10 \%$, they were left out of the final models. Father's country of birth is not collected on California birth certificates.

We additionally examined associations between cancers and average $\mathrm{PM}_{2.5}$ concentrations measured at stations during the entire pregnancy. For these analyses, we restricted our study population to children with addresses at birth that were within 5 miles $(\simeq 8 \mathrm{~km})$ of a CARB air monitoring station. The distance from each participant's home to each air-monitoring station was assessed using ArcView GIS software (version 3.3; ESRI, Redlands, CA). Average concentrations during pregnancy were based on hourly and 24-hr average measurements of $\mathrm{PM}_{2.5}$, with most stations recording measurements every 3 days.

We also estimated associations with traffic density, based on 2002 average annual daily traffic data. Traffic densities were calculated on a $20 \times 20 \mathrm{~m}$ grid using the kernel density plotting feature of Spatial Analyst in ArcInfo GIS 9.1 (ESRI), which effectively caused the densities to decrease from volumedependent values at roadway edges to zero at $500-\mathrm{m}$ perpendicular distance from roadways. The 500-m distance was chosen for consistency with previous studies (Reynolds et al. 2001, 2004), but we also estimated associations with traffic density using 300-m and 1,000-m buffers.

For ALL cases, we conducted stratified analyses to determine whether associations differed by the age at diagnosis $(<1$ year or $\geq 1$ year). Because one-third of California births occur in Los Angeles County, we also conducted sensitivity analyses to determine whether associations with ALL differed between children born in Los Angeles County versus the rest of the state. We also estimated associations separately for the two most common histologic subtypes of germ cell tumors (yolk sac tumors and teratomas). Finally, we estimated associations with quartiles of $\mathrm{CO}$ exposure during each pregnancy period, which were defined based on the exposure distribution among controls. All regression analyses included the covariates listed above.

\section{Results}

We report sociodemographic characteristics of cases and controls in Table 1. There were differences from controls for each covariate in

Table 1. Demographic and socioeconomic characteristics of cases and controls.

\begin{tabular}{|c|c|c|c|c|c|c|c|c|c|c|c|c|c|c|c|}
\hline Characteristic & Controls & ALL & AML & $\mathrm{NHL}$ & $\begin{array}{c}\text { Epen- } \\
\text { dymoma }\end{array}$ & $\begin{array}{l}\text { Astro- } \\
\text { cytomas }\end{array}$ & $\begin{array}{l}\text { Intracranial } \\
\text { and } \\
\text { intraspinal } \\
\text { embryonal } \\
\text { tumors }\end{array}$ & $\begin{array}{l}\text { Medullo- } \\
\text { blastoma }\end{array}$ & PNET & $\begin{array}{c}\text { Neuro- } \\
\text { blastoma }\end{array}$ & $\begin{array}{c}\text { Retino- } \\
\text { blastoma }\end{array}$ & $\begin{array}{l}\text { Wilms } \\
\text { tumor }\end{array}$ & $\begin{array}{l}\text { Hepato- } \\
\text { blastoma }\end{array}$ & $\begin{array}{c}\text { Rhabdomyo- } \\
\text { sarcoma }\end{array}$ & $\begin{array}{c}\text { Germ } \\
\text { cell } \\
\text { tumors }\end{array}$ \\
\hline$n$ & 80,224 & 1,280 & 229 & 78 & 125 & 282 & 205 & 99 & 65 & 417 & 254 & 298 & 127 & 144 & 140 \\
\hline \multicolumn{16}{|l|}{ Mother's race/ethnicity (\%) } \\
\hline Non-Hispanic white & 30.6 & $30.7^{*}$ & 30.1 & 42.3 & 34.4 & $42.2^{*}$ & 36.6 & 35.4 & 32.3 & $42.2^{*}$ & 29.1 & $37.2^{*}$ & 34.6 & 29.9 & $25.7^{*}$ \\
\hline Hispanic & 50.0 & 54.5 & 53.3 & 46.2 & 52.0 & 42.9 & 45.4 & 47.5 & 49.2 & 39.8 & 50.4 & 45.6 & 50.4 & 46.5 & 47.9 \\
\hline Non-Hispanic black & 6.1 & 2.9 & 4.8 & 2.6 & 5.6 & 5.0 & 5.9 & 6.1 & 7.7 & 5.5 & 5.5 & 9.1 & 3.9 & 8.3 & 5.0 \\
\hline Other/not specified & 13.3 & 11.9 & 11.8 & 9.0 & 8.0 & 9.9 & 12.2 & 11.1 & 10.8 & 12.5 & 15.0 & 8.1 & 11.0 & 15.3 & 21.4 \\
\hline \multicolumn{16}{|l|}{ Mother's years of education (\%) } \\
\hline$\leq 8$ & 11.4 & 11.7 & 16.5 & 4.0 & 8.2 & 8.6 & 6.9 & 4.1 & 14.1 & $8.4^{*}$ & $5.3^{*}$ & $9.5^{*}$ & 17.5 & 9.9 & 15.4 \\
\hline $9-<12$ & 18.4 & 17.1 & 15.2 & 28.0 & 18.0 & 14.4 & 20.2 & 24.5 & 18.8 & 14.0 & 21.5 & 13.3 & 15.9 & 16.2 & 16.9 \\
\hline 12 & 28.3 & 30.4 & 29.9 & 29.3 & 28.7 & 28.1 & 26.1 & 29.6 & 23.4 & 29.7 & 30.1 & 34.7 & 26.2 & 27.5 & 30.1 \\
\hline $13-15$ & 19.6 & 18.3 & 17.0 & 14.7 & 23.0 & 22.3 & 21.7 & 20.4 & 17.2 & 19.9 & 22.8 & 18.7 & 19.0 & 19.7 & 19.1 \\
\hline$\geq 16$ & 22.2 & 22.6 & 21.4 & 24.0 & 22.1 & 26.6 & 25.1 & 21.4 & 26.6 & 28.0 & 20.3 & 23.8 & 21.4 & 26.8 & 18.4 \\
\hline \multicolumn{16}{|l|}{ Mother's birthplace (\%) } \\
\hline Mexico & 27.6 & 28.2 & 30.1 & 20.5 & 22.6 & $21.7^{*}$ & 20.5 & 20.2 & 23.1 & $20.1^{*}$ & 22.0 & $22.1^{*}$ & 29.9 & 27.1 & 29.3 \\
\hline Other foreign & 18.9 & 16.6 & 20.1 & 15.4 & 14.5 & 15.7 & 22.9 & 22.2 & 26.2 & 18.0 & 19.3 & 14.4 & 16.5 & 21.5 & 24.3 \\
\hline USA & 53.5 & 55.2 & 49.8 & 64.1 & 62.9 & 62.6 & 56.6 & 57.6 & 50.8 & 61.9 & 58.7 & 63.4 & 53.5 & 51.4 & 46.4 \\
\hline \multicolumn{16}{|l|}{ Parity (\%) } \\
\hline 0 & 39.0 & 36.0 & $40.6^{*}$ & 43.6 & 36.0 & $45.4^{*}$ & 45.4 & $51.5^{*}$ & 36.9 & 41.0 & $40.6^{*}$ & $40.3^{*}$ & 38.6 & 37.5 & 32.9 \\
\hline 1 & 32.0 & 32.7 & 24.9 & 30.8 & 31.2 & 31.6 & 31.2 & 25.3 & 43.1 & 34.5 & 25.2 & 26.5 & 32.3 & 34.7 & 40.0 \\
\hline$\geq 2$ & 28.9 & 31.3 & 34.5 & 25.6 & 32.8 & 23.0 & 23.4 & 23.2 & 20.0 & 24.5 & 34.3 & 33.2 & 29.1 & 27.8 & 27.1 \\
\hline \multicolumn{16}{|l|}{ Father's race/ethnicity (\%) } \\
\hline Non-Hispanic white & 29.2 & $31.8^{*}$ & 25.8 & 34.6 & 30.4 & $40.1^{*}$ & 36.6 & 30.3 & 35.4 & $38.1^{*}$ & 28.3 & $37.9 *$ & 33.9 & 31.3 & 25.0 \\
\hline Hispanic of any race & 46.6 & 49.8 & 52.4 & 48.7 & 49.6 & 40.4 & 40.5 & 43.4 & 43.1 & 38.8 & 44.9 & 43.6 & 49.6 & 44.4 & 46.4 \\
\hline Non-Hispanic black & 6.6 & 3.4 & 6.6 & 2.6 & 7.2 & 6.7 & 6.8 & 7.1 & 7.7 & 6.5 & 5.9 & 8.1 & 4.7 & 6.9 & 4.3 \\
\hline Other/not specified & 17.5 & 15.0 & 15.3 & 14.1 & 12.8 & 12.8 & 16.1 & 19.2 & 13.8 & 16.5 & 20.9 & 10.4 & 11.8 & 17.4 & 24.3 \\
\hline \multicolumn{16}{|c|}{ Source of payment for prenatal care (\%) } \\
\hline Private insurance, $\mathrm{HMO}$ & 52.6 & $57.2^{*}$ & 51.5 & 60.3 & $63.6^{*}$ & $64.5^{*}$ & 57.8 & 53.5 & 51.6 & $58.6^{*}$ & 55.7 & $59.7^{*}$ & 50.4 & 59.9 & 52.9 \\
\hline Medi-Cal/other govt/self-pay & 47.4 & 42.8 & 48.5 & 39.7 & 36.4 & 35.5 & 42.2 & 46.5 & 48.4 & 41.4 & 44.3 & 40.3 & 49.6 & 40.1 & 47.1 \\
\hline \multicolumn{16}{|c|}{ Neighborhood socioeconomic index (\%) } \\
\hline 1 (low) & 27.9 & 27.6 & $28.8^{*}$ & 28.2 & 21.6 & 24.5 & 23.4 & 24.2 & 27.7 & 23.7 & 30.7 & 24.5 & 28.3 & 29.2 & 19.3 \\
\hline 2 & 23.7 & 23.0 & 27.9 & 28.2 & 29.6 & 23.0 & 28.3 & 34.3 & 20.0 & 24.5 & 22.0 & 24.5 & 16.5 & 19.4 & 29.3 \\
\hline 3 & 19.3 & 20.2 & 15.7 & 11.5 & 21.6 & 18.4 & 18.0 & 14.1 & 23.1 & 20.9 & 20.1 & 20.1 & 17.3 & 22.9 & 22.9 \\
\hline 4 & 15.4 & 15.2 & 14.4 & 21.8 & 12.0 & 17.7 & 16.6 & 13.1 & 20.0 & 15.8 & 13.8 & 17.4 & 17.3 & 11.8 & 15.0 \\
\hline 5 (high) & 13.7 & 13.9 & 12.7 & 10.3 & 15.2 & 16.3 & 13.7 & 14.1 & 9.2 & 15.1 & 13.4 & 13.4 & 20.5 & 16.7 & 13.6 \\
\hline
\end{tabular}

govt, government.

${ }^{*} p<0.05$ from chi-square testing. 
relation to at least one of the cancer outcomes assessed. Maternal years of education was missing for $2 \%$ of the sample, with no differences in the amount of missing by case status; all other covariates had $<1 \%$ missing data.

Across the time periods, modeled $\mathrm{CO}$ values were highly correlated (Table 2). Correlations were weaker between CALINE4 $\mathrm{CO}$ measures and both traffic density and $\mathrm{PM}_{2.5}$. We observed elevated odds for specific childhood cancers and traffic-related air pollutants and specific childhood cancers across gestation and in the first year of life; because of strong correlations across time periods, we do not present second- and and thirdtrimester results (Table 3). IQR increases of modeled CO were positively associated with ALL, retinoblastoma (overall and bilateral only), and germ cell tumors; increases in PNET, ependymomas, and NHL were also observed. Associations between $\mathrm{CO}$ and germ cell tumors appeared to be driven by associations with teratomas. We also estimated a negative association between AML and an IQR increase in CO during the first trimester.
In comparing results across California, the association between ALL and CO exposure during the child's first year was similar for children residing in LA County [odds ratio $(\mathrm{OR})=1.06 ; 95 \% \mathrm{CI}: 1.00,1.12]$ and in the rest of the state $(\mathrm{OR}=1.08 ; 95 \% \mathrm{CI}$ : $0.99,1.17)$. When ALL cases were stratified by age at diagnosis, we estimated stronger associations with cases diagnosed during the first year of life $(\mathrm{OR}=1.14 ; 95 \% \mathrm{CI}$ : $0.99,1.31$ based on 81 cases) than cases diagnosed at $1-5$ years of age $(\mathrm{OR}=1.04 ; 95 \%$ CI: $1.00,1.09$ based on 1,149 cases).

Associations with IQR increases in average $\mathrm{PM}_{2.5}$ exposures during pregnancy $\left(7.84 \mu \mathrm{g} / \mathrm{m}^{3}\right)$ and with an IQR increase in traffic density within $500 \mathrm{~m}$ of the residence at birth (68 vehicle number per day $\times$ meter/ meter $^{2}$ ) are shown in Table 4. Although sample sizes were smaller, the patterns observed in CALINE4 modeled CO were generally similar to associations with IQR increases in $\mathrm{PM}_{2.5}$, except that no association was observed between $\mathrm{PM}_{2.5}$ and germ cell tumors. Associations with traffic density tended to be closer to the null than those generated using CALINE4, regardless of the buffer distance used (results for $300 \mathrm{~m}$ and 1,000 $\mathrm{m}$ not shown).

When CALINE4-based CO exposures across the time periods were categorized into quartiles, we observed similar patterns of findings to those seen when we conducted regression analyses based on the interquartile range (data not shown). For ALL, the point estimates were slightly increased across the quartiles relative to the lowest quartile (2nd quartile: $\mathrm{OR}=1.07 ; 95 \% \mathrm{CI}: 0.90,1.27$; 3rd quartile: $\mathrm{OR}=1.14$; 95\% CI: 0.96, 1.35; highest quartile: $\mathrm{OR}=1.12: 95 \% \mathrm{CI}$ : $0.94,1.34)$. For retinoblastoma, we estimated stronger ORs at the highest quartile (2nd quartile: $\mathrm{OR}=1.10 ; 95 \% \mathrm{CI}: 0.75,1.62$; 3rd quartile: $\mathrm{OR}=1.12 ; 95 \% \mathrm{CI}: 0.76,1.66$; highest quartile: $\mathrm{OR}=1.50 ; 95 \% \mathrm{CI}$ : $1.02,2.19)$. Teratomas also exhibited higher ORs at the highest quartile (2nd quartile: $\mathrm{OR}=1.27: 95 \%$ CI: $0.63,2.56$; 3 rd quartile: $\mathrm{OR}=0.90 ; 95 \% \mathrm{CI}: 0.41,1.98$; highest quartile: $\mathrm{OR}=2.10,95 \% \mathrm{CI}: 1.06,4.16)$.

Table 2. Descriptive statistics of air pollution measures and Pearson correlation coefficients across time periods.

\begin{tabular}{|c|c|c|c|c|c|c|c|c|c|c|c|}
\hline \multirow[b]{2}{*}{ Measure } & \multirow[b]{2}{*}{$n$} & \multirow[b]{2}{*}{ Mean \pm SD } & \multirow[b]{2}{*}{ IQR } & \multicolumn{4}{|c|}{ CALINE4 modeled CO } & \multirow{2}{*}{ 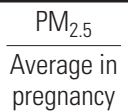 } & \multicolumn{3}{|c|}{ Traffic density } \\
\hline & & & & $\begin{array}{l}1 \mathrm{st} \\
\text { trimester }\end{array}$ & $\begin{array}{c}\text { 2nd } \\
\text { trimester }\end{array}$ & $\begin{array}{c}\text { 3rd } \\
\text { trimester }\end{array}$ & $\begin{array}{l}\text { Child's } \\
\text { 1st year }\end{array}$ & & $\begin{array}{l}\text { Within } \\
300 \mathrm{~m}\end{array}$ & $\begin{array}{l}\text { Within } \\
500 \mathrm{~m}\end{array}$ & $\begin{array}{l}\text { Within } \\
1,000 \mathrm{~m}\end{array}$ \\
\hline \multicolumn{12}{|c|}{ CALINE4-modeled CO (ppm) } \\
\hline 2nd trimester & 82,308 & $0.0555 \pm 0.0644$ & 0.0530 & 0.97 & 1.00 & & & & & & \\
\hline 3rd trimester & 77,167 & $0.0551 \pm 0.0647$ & 0.0528 & 0.96 & 0.98 & 1.00 & & & & & \\
\hline 1 st year average & 81,003 & $0.0548 \pm 0.0633$ & 0.0523 & 0.97 & 0.97 & 0.98 & 1.00 & & & & \\
\hline $\mathrm{PM}_{2.5}\left(\mu \mathrm{g} / \mathrm{m}^{3}\right)$ & 56,548 & $17.21 \pm 5.09$ & 8.1 & 0.22 & 0.22 & 0.21 & 0.22 & 1.00 & & & \\
\hline Within 500 m & 83,814 & $71.05 \pm 97.68$ & 67.75 & 0.74 & 0.75 & 0.75 & 0.76 & 0.09 & 0.90 & 1.00 & \\
\hline Within 1,000 m & 83,814 & $75.53 \pm 79.43$ & 68.84 & 0.81 & 0.81 & 0.81 & 0.82 & 0.13 & 0.66 & 0.86 & 1.00 \\
\hline
\end{tabular}

$\mathrm{PM}_{2.5}$ was measured at the closest community air monitor located within 5 miles of the child's residence. Traffic density was calculated using traffic count data at major roads near the residence.

Table 3. ORs $(95 \% \mathrm{CIs})$ for cancer risk for 1 IQR increase in CO, using CALINE4 air pollution modeling. ${ }^{a}$

\begin{tabular}{|c|c|c|c|c|c|}
\hline \multirow[b]{2}{*}{ Outcome } & \multirow[b]{2}{*}{$n$ cases } & \multicolumn{2}{|c|}{$\begin{array}{c}\text { Average traffic exposure } \\
\text { in the } 1 \text { st trimester of pregnancy }\end{array}$} & \multicolumn{2}{|c|}{ Average traffic exposure in the child's first year } \\
\hline & & Model $1^{b}$ & Model $2^{c}$ & Model $1^{b}$ & Model $2^{c}$ \\
\hline$\overline{A L L}$ & 1,280 & $1.03(0.99,1.08)$ & $1.05(1.01,1.10)$ & $1.04(0.99,1.08)$ & $1.05(1.01,1.10)$ \\
\hline AML & 229 & $0.87(0.75,1.00)$ & $0.85(0.73,0.98)$ & $0.94(0.82,1.08)$ & $0.91(0.79,1.05)$ \\
\hline $\mathrm{NHL}$ & 78 & $1.07(0.92,1.25)$ & $1.10(0.95,1.28)$ & $1.06(0.89,1.25)$ & $1.08(0.92,1.28)$ \\
\hline Ependymoma & 125 & $1.04(0.90,1.19)$ & $1.08(0.94,1.24)$ & $1.07(0.94,1.23)$ & $1.11(0.97,1.27)$ \\
\hline Astrocytoma & 282 & $0.89(0.80,1.01)$ & $0.94(0.84,1.06)$ & $0.89(0.79,1.01)$ & $0.95(0.84,1.06)$ \\
\hline Intracranial and intraspinal embryonal tumors & 205 & $0.99(0.88,1.11)$ & $0.99(0.87,1.12)$ & $1.01(0.89,1.14)$ & $1.01(0.89,1.15)$ \\
\hline Primitive neuroectodermal tumor & 65 & $1.08(0.91,1.28)$ & $1.04(0.86,1.25)$ & $1.10(0.93,1.31)$ & $1.07(0.89,1.29)$ \\
\hline Medulloblastoma & 99 & $0.94(0.78,1.12)$ & $0.93(0.77,1.13)$ & $0.95(0.79,1.14)$ & $0.95(0.79,1.15)$ \\
\hline Neuroblastoma & 417 & $0.95(0.87,1.04)$ & $0.98(0.89,1.07)$ & $0.97(0.89,1.06)$ & $1.00(0.91,1.09)$ \\
\hline Retinoblastoma & 254 & $1.10(1.01,1.20)$ & $1.11(1.01,1.21)$ & $1.11(1.02,1.22)$ & $1.12(1.02,1.23)$ \\
\hline Unilateral & 165 & $1.07(0.95,1.20)$ & $1.08(0.96,1.22)$ & $1.07(0.95,1.21)$ & $1.08(0.95,1.22)$ \\
\hline Bilateral & 87 & $1.15(1.01,1.31)$ & $1.16(1.02,1.33)$ & $1.18(1.04,1.34)$ & $1.19(1.05,1.36)$ \\
\hline Wilms tumor & 298 & $0.88(0.78,0.99)$ & $0.91(0.81,1.03)$ & $0.88(0.78,0.99)$ & $0.91(0.81,1.03)$ \\
\hline Hepatoblastoma & 127 & $0.94(0.80,1.12)$ & $0.95(0.80,1.13)$ & $0.98(0.83,1.15)$ & $0.98(0.82,1.16)$ \\
\hline Rhabdomyosarcoma & 144 & $0.95(0.82,1.11)$ & $0.91(0.77,1.08)$ & $0.95(0.81,1.11)$ & $0.90(0.75,1.07)$ \\
\hline Germ cell tumors & 140 & $1.14(1.02,1.27)$ & $1.16(1.04,1.29)$ & $1.15(1.03,1.28)$ & $1.17(1.05,1.31)$ \\
\hline Yolk sac tumors & 49 & $0.95(0.72,1.24)$ & $0.92(0.68,1.24)$ & $0.92(0.68,1.23)$ & $0.89(0.64,1.23)$ \\
\hline Teratomas & 72 & $1.24(1.11,1.39)$ & $1.26(1.12,1.41)$ & $1.25(1.11,1.41)$ & $1.27(1.13,1.43)$ \\
\hline
\end{tabular}

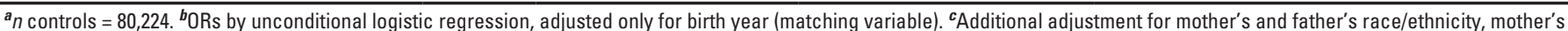
years of education, mother's country of birth, parity, method of payment for prenatal care, and neighborhood socioeconomic index. 


\section{Discussion}

In this large population-based study, we observed positive associations of ALL, retinoblastoma, and teratomas with model-based estimates of traffic-related air pollution exposures during pregnancy and early childhood. Because of strong correlations of our modeled air pollutant exposure estimates across all three trimesters of pregnancy and the first year of life, we were not able to identify variation in associations according to time period. Leukemias have been studied at length in relation to traffic pollution, and our findings are consonant with what has been observed in most previous studies, which have showed increases in risk for leukemias with exposure both during pregnancy and in childhood (Amigou et al. 2011; Crosignani et al. 2004; Feychting et al. 1998; Vinceti et al. 2012; Weng et al. 2008). Although specific biological mechanisms underlying associations between air pollution and cancer are not known, experimental evidence indicates PM exposure instigates an immune response which increases TLR (toll-like receptor) (Shoenfelt et al. 2009) and RAGE (receptors for advanced glycation end-products) expression (Reynolds et al. 2011). These signaling pathways have been implicated in tumor growth and metastasis (Grimm et al. 2010; Sims et al. 2010).

Traffic-related air pollution exposure was positively associated with both unilateral and bilateral retinoblastoma, although associations with bilateral disease were stronger. Retinal abnormalities have been observed in neonates whose mothers smoked in pregnancy (Beratis et al. 2000), and CO, in higher doses, is known to cause retinal damage (Kelley and Sophocleus 1978; Resch et al. 2005).
There have been few epidemiologic studies of retinoblastoma that examined environmental exposures. In one study, paternal occupational exposure to exhaust fumes was not related to increases in bilateral retinoblastoma, although the number of exposed cases was small $(\mathrm{OR}=1.2 ; 95 \% \mathrm{CI}: 0.6,2.4)$ (MacCarthy et al. 2009).

Although teratomas were associated with traffic pollution when modeled using CALINE4 and traffic density, these associations were not replicated in our $\mathrm{PM}_{2.5}$-based analyses, suggesting that the association with teratomas might reflect an effect of agents in traffic exhaust that decay quickly over distances. Alternatively, this result may be due to noncausal mechanisms. Teratomas are believed to derive from primordial germ cells that arise in the yolk sac and migrate along the mesentery to the gonadal ridge during the 4th-5th week of development. Cells that incompletely differentiate are hypothesized to give rise to teratomas (Barksdale and Obokhare 2009). Studies in mice have observed that constituents of air pollution can cause retarded gonadal cell migration, immature gonads (Tam and Liu 1985), and germ cell differentiation disorders (Yoshida et al. 2002). Two case-control studies of associations between exposure to exhaust fumes and childhood germ cell tumors (all histologic types combined) did not observe associations with exposure to engine exhaust fumes (Chen et al. 2006; Shu et al. 1995); however, the broader age range $(<15$ years of age) in these studies suggests they would have included larger numbers of histologic types less frequently observed in young children. In a separate study by our group in which traffic pollution was modeled using land-use regression, we observed positive associations with retinoblastoma and ALL, consistent with the present study, but no associations with germ cell tumors; this study included Los Angeles County residents only, and thus had some overlapping participants with the present study (Ghosh et al. 2013).

$\mathrm{PM}_{2.5}$ is an imperfect proxy for trafficrelated air pollution. In urban areas, most $\mathrm{PM}_{2.5}$ pollution occurs directly or indirectly (via reactions of precursors) from traffic exhaust or other combustion, with much of the remainder from construction dust. In rural areas, dust from agricultural operations and wood smoke make up much larger proportions of PM; and along the California coast, another important contributor to PM is sea salt (Cox et al. 2010). Given that 83\% of births in our study occurred in urban areas, gasoline and diesel combustion was the primary contributor to $\mathrm{PM}_{2.5}$ exposures for most children.

We observed a negative association between AML and traffic-related pollution. The possibility exists that this result is attributable to chance. Moreover, in California, AML rates are highest across the rural counties of the Sierra Nevada, the Napa Valley, and the North Coast, suggesting that risk factors more common in rural areas may be more relevant for AML etiology (California Cancer Registry 2012). In the present study, AML cases were $20 \%$ more likely than controls to live in rural counties. Other studies have similarly reported elevated risks for both adult and childhood AML in rural areas (Carozza et al. 2008; Sinner et al. 2005).

A possible reason for the difference in results between ours and other studies may be that some studies included older children

Table 4. ORs $(95 \% \mathrm{Cls})$ for childhood cancer from one IOR increase in traffic pollution exposure, measuring traffic-related air pollution exposure using $\mathrm{PM}_{2.5}$ measured from community air monitors, and traffic density.

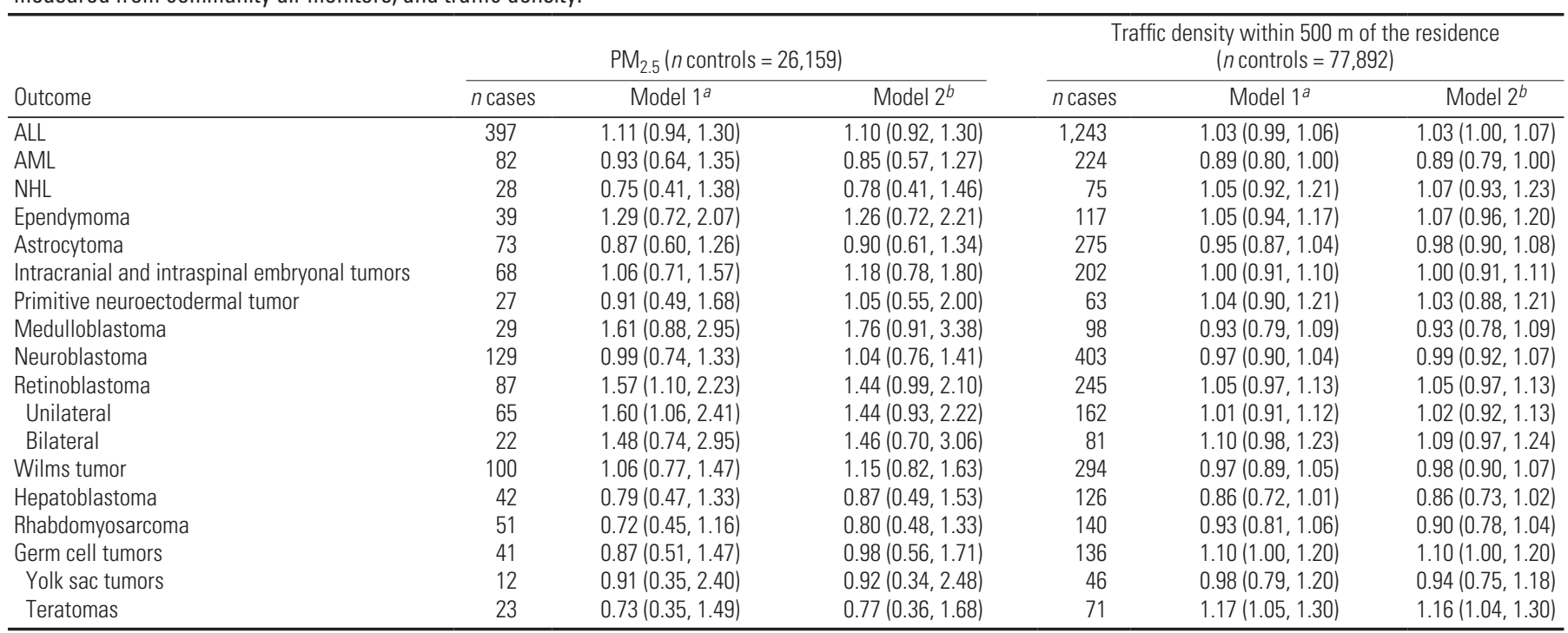

${ }^{a}$ ORs by unconditional logistic regression, adjusted only for birth year (matching variable). ${ }^{b}$ Additional adjustment for mother's and father's race/ethnicity, mother's years of education, mother's country of birth, parity, method of payment for prenatal care, and neighborhood socioeconomic index. 
in analyses. A number of childhood cancer studies have posited that risk factors may differ by the age at diagnosis, and have suggested that any effect from pregnancy exposures may be most relevant for younger children (Cnattingius et al. 1995; Heck et al. 2009; Yeazel et al. 1995). When we stratified ALL cases by the age at diagnosis, average $\mathrm{CO}$ exposures during pregnancy were more strongly associated with ALL diagnosed during the first year of life than cases diagnosed in older children. Similarly, Savitz and Feingold (1989) reported positive associations between all leukemias and traffic exposure among children $<5$ years of age at diagnosis $(\mathrm{OR}=5.6$; 95\% CI: $1.9,16.7)$ but no associations among children 5-14 years of age $(\mathrm{OR}=0.4$; 95\% CI: 0.1, 2.8). Vinceti et al. (2012) also reported similar patterns by age.

There are a large number of components of traffic-related air pollution, including thousands of chemicals and particulates, making it difficult to identify the most relevant chemicals for carcinogenesis. Only 50\% of benzene emissions in California come from mobile sources, so our CALINE4 model should not be interpreted as a model for benzene exposure (Cox et al. 2010). Because of more stringent requirements, gasoline formulations have changed in the United States in recent years, with consequent decreases in $\mathrm{CO}$ emissions observed over the prior two decades. California law has required additional decreases beyond what is allowed in conventional U.S. gasoline, yielding lower emissions of $\mathrm{NO}_{\mathrm{x}}$ and volatile organic chemicals (U.S. General Accounting Office 2005). Despite this, California is known to have among the highest levels of air pollution in the nation. Of the 25 U.S. metropolitan areas with the highest short-term ambient $\mathrm{PM}_{2.5}$ concentrations, 12 are located in California, in part due to the high population density (American Lung Association 2004). In the South Coast Air Basin, where Los Angeles is located, in $2007 \mathrm{PM}_{2.5}$ annually averaged $19.8 \mu \mathrm{g} / \mathrm{m}^{3}$, the maximum 8 -hr CO concentration was $5.3 \mathrm{ppm}$, and the maximum annual average of $\mathrm{NO}_{2}$ was $0.031 \mathrm{ppm}$ (Cox et al. 2010). The pollutant values estimated by our CALINE4 model were lower than those typically recorded at monitoring stations in California. The reason for this discrepancy is that CALINE4 models do not consider contributions from minor surface streets, regional background, or other sources such as industrial emissions, minor roads, or traffic emissions from roads $>1,500 \mathrm{~m}$ away. Thus, our values will be lower than those typically recorded by air pollution monitors. Because of this, and because modeled CO is a marker of traffic pollution rather than a carcinogen, we calculated ORs based upon the IQR of exposure rather than the absolute exposure level.
Although we recommend the use of complex modeling strategies to estimate exposures whenever possible, simple traffic density might often be the only measure feasible to ascertain exposures in the large populations needed for childhood cancer studies. Traffic density has been computed in various ways across different studies (for example, traffic counts per kilometer of road in an area, sum of the miles of road in an area, traffic counts for major roads only), which may affect the validity of findings and the potential for exposure misclassification.

A limitation of our study was the reliance on the birth certificate for the child's address and for information on confounding variables. A recent review found that $9-32 \%$ of women in the United States and abroad, in studies from the 1980s-2000s, move residence during pregnancy, although most moves are local (median distance, $<10 \mathrm{~km}$ ) (Bell and Belanger 2012). We also do not know which mothers worked outside the home during pregnancy, which is likely to influence the accuracy of exposure classification. Birth certificates vary in accuracy depending on the information being collected. Validation studies of birth certificates in California and other U.S. states have indicated that factors such as demographic information and parity have a validity of $>90 \%$ (Baumeister et al. 2000; Northam and Knapp 2006).

Additionally, there may be neighborhood factors that co-vary with traffic exposure that we could not account for in the present study. In our previous work we did not observe associations between exposure to traffic pollution in Los Angeles and family or neighborhood socioeconomic status (Wilhelm et al. 2009); also associations have not been established between socioeconomic status and most childhood cancer types, with the possible exception of Wilms tumor (Adam et al. 2008; Carozza et al. 2010; de Camargo et al. 2011; Heck et al. 2012; Poole et al. 2006). We have previously estimated correlations between estimated exposures to different types of pollutants in California, and observed that persons exposed to high traffic pollution also tend to be exposed to higher levels of three air toxics: lead, styrene, and perchloroethylene (Heck et al. 2013b). Although none of these three air toxics has been definitively associated with childhood cancers, we cannot exclude that they may contribute to risk.

Strengths of the study include the population-based design and inclusion of rarer childhood cancer types. The population was varied as to its rural/urban area of residence, road density and demographic factors. Our record-linkage approach included all children for whom data were available, limiting selection bias; however, we were limited in being able to estimate only the address at birth.
This study provides new evidence suggesting that exposure to traffic-related pollution in pregnancy and early childhood may increase the risk for ALL, retinoblastoma, and germ cell tumors. Further research using complex air pollution models, examining retinoblastoma and other rarer cancer types, is recommended.

\section{CORRECTION}

The IQR value for $\mathrm{PM}_{2.5}$ in Table 2 and the $\mathrm{PM}_{2.5}$ values for PNET and medulloblastoma cases in Table 4 were incorrect in the manuscript originally published online. They have been corrected here.

\section{References}

Abdul Rahman HI, Shah SA, Alias H, Ibrahim HM. 2008. A casecontrol study on the association between environmental factors and the occurrence of acute leukemia among children in Klang Valley, Malaysia. Asian Pac J Cancer Prev 9(4):649-652.

Adam M, Rebholz CE, Egger M, Zwahlen M, Kuehni CE. 2008. Childhood leukaemia and socioeconomic status: what is the evidence? Radiat Prot Dosimetry 132(2):246-254.

Alexander FE, Leon DA, Cartwright RA. 1996. Isolation, car ownership, and small area variation in incidence of acute lymphoblastic leukaemia in children. Paediatr Perinat Epidemiol 10(4):411-417.

American Lung Association. 2004. State of the Air. Washington, DC:American Lung Association.

Amigou A, Sermage-Faure C, Orsi L, Leverger G, Baruchel A, Bertrand $Y$, et al. 2011. Road traffic and childhood leukemia: the ESCALE study (SFCE). Environ Health Perspect 119:566-572; doi:10.1289/ehp.1002429.

Barksdale EM Jr, Obokhare I. 2009. Teratomas in infants and children. Curr Opin Pediatr 21(3):344-349.

Baumeister L, Marchi K, Pearl M, Williams R, Braveman P. 2000. The validity of information on "race" and "Hispanic ethnicity" in California birth certificate data. Health Serv Res 35(4):869-883.

Bell ML, Belanger K. 2012. Review of research on residential mobility during pregnancy: consequences for assessment of prenatal environmental exposures. J Expo Sci Environ Epidemiol 22(5):429-438.

Benbrahim-Tallaa L, Baan RA, Grosse Y, Lauby-Secretan B, El Ghissassi F, Bouvard V, et al. 2012. Carcinogenicity of diesel-engine and gasoline-engine exhausts and some nitroarenes. Lancet Oncol 13(7):663-664.

Benson P. 1989. CALINE4: A Dispersion Model for Predicting Air Pollutant Concentrations Near Roadways. Sacramento, CA:California Department of Transportation.

Benson PE. 1992. A review of the development and application of the CALINE3 and CALINE4 models. Atmos Environ Part B Urban Atmos 26(3):379-390.

Beratis NG, Varvarigou A, Katsibris J, Gartaganis SP. 2000 Vascular retinal abnormalities in neonates of mothers who smoked during pregnancy. J Pediatr 136(6):760-766.

Broderick BM, Budd U, Misstear BD, Ceburnis D, Jennings SG 2005. Validation of CALINE4 modelling for carbon monoxide concentrations under free-flowing and congested traffic conditions in Ireland. Int J Environ Pollu 24(1-4):104-113.

Brosselin P, Rudant J, Orsi L, Leverger G, Baruchel A, Bertrand Y, et al. 2009. Acute childhood leukaemia and residence next to petrol stations and automotive repair garages: the ESCALE study (SFCE). Occup Environ Med 66(9):598-606.

CARB (California Air Resources Board). 2007. EMFAC2007. Available: http://www.arb.ca.gov/msei/onroad/downloads/ docs/user_guide_emfac2007.pdf [accessed 20 March 2011].

CARB (California Air Resources Board). 2010. Air Quality and Meteorological Information System. Available: http://www.arb.ca.gov/aqmis2/aqmis2.php [accessed 18 February 2010].

California Cancer Registry. 2012. Invasive Cancer Incidence Rates by County in California. Available: http://www. cancer-rates.info/ca [accessed 10 November 2012]. 
Carozza SE, Li B, Elgethun K, Whitworth R. 2008. Risk of childhood cancers associated with residence in agriculturally intense areas in the United States. Environ Health Perspect 116:559-565.; doi:10.1289/ehp.9967.

Carozza SE, Puumala SE, Chow EJ, Fox EE, Horel S, Johnson KJ, et al. 2010. Parental educational attainment as an indicator of socioeconomic status and risk of childhood cancers. Br J Cancer 103(1):136-142.

Chen Z, Robison L, Giller R, Krailo M, Davis M, Davies S, et al. 2006. Environmental exposure to residential pesticides, chemicals, dusts, fumes, and metals, and risk of childhood germ cell tumors. Int J Hyg Environ Health 209(1):31-40.

Cnattingius S, Zack MM, Ekbom A, Gunnarskog J, Kreuger A, Linet $M$, et al. 1995. Prenatal and neonatal risk factors for childhood lymphatic leukemia. J Natl Cancer Inst 87(12):908-914.

Cox P, Delao A, Komorniczak A, Weller R. 2010. The California Almanac of Emissions and Air Quality-2009 Edition. Sacramento, CA:California Air Resources Board. Available: http://www.arb.ca.gov/aqd/almanac/ almanac09/almanac09.htm [accessed 29 0ctober 2013]

Crosignani P, Tittarelli A, Borgini A, Codazzi T, Rovelli A, Porro $E$, et al. 2004. Childhood leukemia and road traffic: a population-based case-control study. Int J Cancer 108(4):596-599.

de Camargo B, de Oliveira Ferreira JM, de Souza Reis R, Ferman S, de Oliveira Santos M, Pombo-de-Oliveira MS 2011. Socioeconomic status and the incidence of noncentral nervous system childhood embryonic tumours in Brazil. BMC Cancer 11:160; doi:10.1186/1471-2407-11-160.

Dockerty JD, Draper G, Vincent T, Rowan SD, Bunch KJ. 2001. Case-control study of parental age, parity and socioeconomic level in relation to childhood cancers. Int $J$ Epidemiol 30(6):1428-1437.

Feychting M, Svensson D, Ahlbom A. 1998. Exposure to motor vehicle exhaust and childhood cancer. Scand J Work Environ Health 24(1):8-11.

Fritz A, ed. 2000. International Classification of Diseases for Oncology: ICD-0. Geneva:World Health Organization.

Gauderman WJ, Avol E, Lurmann F, Kuenzli N, Gilliland F, Peters J, et al. 2005. Childhood asthma and exposure to traffic and nitrogen dioxide. Epidemiology 16(6):737-743.

Ghosh JK, Heck JE, Cockburn M, Su J, Jerrett M, Ritz B. 2013. Prenatal exposure to traffic-related air pollution and risk of early childhood cancers. Am J Epidemiol 178(8):1233-1239; doi:10.1093/aje/kwt129 [Online 28 August 2013].

Goldberg DW, Wilson JP, Knoblock CA, Ritz B, Cockburn MG. 2008. An effective and efficient approach for manually improving geocoded data. Int J Health Geogr 7:60; doi:10.1186/1476-072X-7-60

Greaves MF, Wiemels J. 2003. Origins of chromosome translocations in childhood leukaemia. Nat Rev Cancer 3(9):639-649.

Grimm M, Kim M, Rosenwald A, Heemann U, Germer CT, Waaga-Gasser AM, et al. 2010. Toll-like receptor (TLR) 7 and TLR8 expression on $\mathrm{CD}_{133^{+}}$cells in colorectal cancer points to a specific role for inflammation-induced TLRs in tumourigenesis and tumour progression. Eur $\mathrm{J}$ Cancer 46(15):2849-2857.

Harrison RM, Leung PL, Somervaille L, Smith R, Gilman E. 1999. Analysis of incidence of childhood cancer in the West Midlands of the United Kingdom in relation to proximity to main roads and petrol stations. Occup Environ Med 56(11):774-780.

Heck JE, Lombardi CA, Cockburn M, Meyers TJ, Wilhelm M, Ritz B. 2013a. Epidemiology of rhabdoid tumors of early childhood. Pediatr Blood Cancer 60(1):77-81.

Heck JE, Lombardi CA, Meyers TJ, Cockburn M, Wilhelm M, Ritz B. 2012. Perinatal characteristics and retinoblastoma. Cancer Causes Contr 23(9):1567-1575.

Heck JE, Park AS, Qiu J, Cockburn M, Ritz B. 2013b. An exploratory study of ambient air toxics exposure in pregnancy and the risk of neuroblastoma in offspring. Environ Res; doi: 10.1016/j.envres.2013.09.002 [Online 16 October 2013].

Heck JE, Ritz B, Hung RJ, Hashibe M, Boffetta P. 2009. The epidemiology of neuroblastoma: a review. Paediatr Perinat Epidemiol 23(2):125-143.

Houston D, Wu J, Ong P, Winer A. 2004. Structural disparities of urban traffic in southern California: implications for vehicle-related air pollution exposure in minority and highpoverty neighborhoods. J Urban Affairs 26(5):565-592.

Hu SS, Fruin S, Kozawa K, Mara S, Paulson SE, Winer AM. 2009. A wide area of air pollutant impact downwind of a freeway during pre-sunrise hours. Atmos Environ 43(16):2541-2549.

ARC (International Agency for Research on Cancer). 2012 A review of human carcinogens: chemical agents and related occupations. IARC Monogr Eval Carcinog Risk Hum 100F:1-599.

Johnson KJ, Soler JT, Puumala SE, Ross JA, Spector LG. 2008 Parental and infant characteristics and childhood leukemia in Minnesota. BMC Pediatrics 8:7; doi:10.1186/1471-2431-8-7.

Kelley JS, Sophocleus GJ. 1978. Retinal hemorrhages in subacute carbon monoxide poisoning. Exposures in homes with blocked furnace flues. JAMA 239(15):1515-1517.

Lafiura KM, Bielawski DM, Posecion NC Jr, Ostrea EM Jr, Matherly LH, Taub JW, et al. 2007. Association between prenatal pesticide exposures and the generation of leukemiaassociated T(8;21). Pediatr Blood Cancer 49(5):624-628.

Langholz B, Ebi KL, Thomas DC, Peters JM, London SJ. 2002. Traffic density and the risk of childhood leukemia in a Los Angeles case-control study. Ann Epidemiol 12(7):482-487.

Levitin J, Harkonen J, Kukkonen J, Nikmo J. 2005. Evaluation of the CALINE4 and CAR-FMI models against measurements near a major road. Atmos Environ 39(25):4439-4452.

MacCarthy A, Bunch KJ, Fear NT, King JC, Vincent TJ, Murphy MF. 2009. Paternal occupation and retinoblas toma: a case-control study based on data for Great Britain 1962-1999. Occup Environ Med 66(10):644-649.

Nordlinder R, Jarvholm B. 1997. Environmental exposure to gasoline and leukemia in children and young adults-an ecology study. Int Arch 0ccup Environ Health 70(1):57-60.

Northam S, Knapp TR. 2006. The reliability and validity of birth certificates. J Obstet Gynecol Neonatal Nurs 35(1):3-12.

Pearson RL, Wachtel H, Ebi KL. 2000. Distance-weighted traffic density in proximity to a home is a risk factor for leukemia and other childhood cancers. J Air Waste Manag Assoc 50(2):175-180.

Poole C, Greenland S, Luetters C, Kelsey JL, Mezei G. 2006. Socioeconomic status and childhood leukaemia: a review. Int J Epidemiol 35(2):370-384.

Raaschou-Nielsen 0, Hertel 0, Thomsen BL, Olsen JH. 2001. Air pollution from traffic at the residence of children with cancer. Am J Epidemiol 153(5):433-443.

Resch H, Zawinka C, Weigert G, Schmetterer L, Garhofer G. 2005. Inhaled carbon monoxide increases retinal and choroidal blood flow in healthy humans. Invest Ophthalmol Vis Sci 46(11):4275-4280.

Reynolds P, Elkin E, Scalf R, Von Behren J, Neutra RR. 2001. A case-control pilot study of traffic exposures and early childhood leukemia using a geographic information system. Bioelectromagnetics Suppl 5:S58-S68.

Reynolds P, Von Behren J, Gunier RB, Goldberg DE, Hertz A. 2004. Residential exposure to traffic in California and childhood cancer. Epidemiology 15(1):6-12.

Reynolds P, Von Behren J, Gunier RB, Goldberg DE, Hertz A Smith D. 2002. Traffic patterns and childhood cancer incidence rates in California, United States. Cancer Causes Control 13(7):665-673.

Reynolds PR, Wasley KM, Allison CH. 2011. Diesel particulate matter induces receptor for advanced glycation end products (RAGE) expression in pulmonary epithelial cells, and RAGE signaling influences NF- $\mathrm{KB}$-mediated inflammation. Environ Health Perspect 119:332-336; doi:10.1289/ ehp. 1002520

Ritz B, Wilhelm M, Hoggatt KJ, Ghosh JK. 2007. Ambient air pollution and preterm birth in the environment and pregnancy outcomes study at the University of California, Los Angeles. Am J Epidemiol 166(9):1045-1052.

Savitz DA, Feingold L. 1989. Association of childhood cance with residential traffic density. Scand J Work Environ Health 15(5):360-363.

Schuz J, Kaatsch P, Kaletsch U, Meinert R, Michaelis J. 1999. Association of childhood cancer with factors related to pregnancy and birth. Int J Epidemiol 28(4):631-639.

Selevan SG, Kimmel CA, Mendola P. 2000. Identifying critical windows of exposure for children's health. Environ Health Perspect 108(suppl 3):451-455.
Shoenfelt J, Mitkus RJ, Zeisler R, Spatz R0, Powell J, Fenton MJ, et al. 2009. Involvement of TLR2 and TLR4 in inflammatory immune responses induced by fine and coarse ambient air particulate matter. J Leukoc Biol 86(2):303-312; doi:10.1189/jlb.1008587.

Shu XO, Nesbit ME, Buckley JD, Krailo MD, Robinson LL. 1995. An exploratory analysis of risk factors for childhood malignant germ-cell tumors: report from the Childrens Cancer Group (Canada, United States). Cancer Causes Control 6(3):187-198.

Sims GP, Rowe DC, Rietdijk ST, Herbst R, Coyle AJ. 2010 HMGB1 and RAGE in inflammation and cancer. Annu Rev Immunol 28:367-388.

Sinner PJ, Cerhan JR, Folsom AR, Ross JA. 2005. Positive association of farm or rural residence with acute myeloid leukemia incidence in a cohort of older women. Cancer Epidemiol Biomarkers Prev 14(10):2446-2448.

Steffen C, Auclerc MF, Auvrignon A, Baruchel A, Kebaili K, Lambilliotte $A$, et al. 2004. Acute childhood leukaemia and environmental exposure to potential sources of benzene and other hydrocarbons; a case-control study. 0ccup Environ Med 61(9):773-778.

Steliarova-Foucher E, Stiller C, Lacour B, Kaatsch P. 2005. International Classification of Childhood Cancer, 3rd Edition. Cancer 103(7):1457-1467.

Tam PP, Liu WK. 1985. Gonadal development and fertility of mice treated prenatally with cadmium during the early organogenesis stages. Teratology 32(3):453-462.

U.S. General Accounting Office. 2005. Special Gasoline Blends Reduce Emissions and Improve Air Quality, but Complicate Supply and Contribute to Higher Prices. Washington, DC:U.S. General Accounting Office.

Vinceti M, Rothman KJ, Crespi CM, Sterni A, Cherubini A Guerra L, et al. 2012. Leukemia risk in children exposed to benzene and $\mathrm{PM}_{10}$ from vehicular traffic: a case control study in an Italian population. Eur J Epidemiol 27(10):781-790.

Visser 0, van Wijnen JH, van Leeuwen FE. 2004. Residential traffic density and cancer incidence in Amsterdam 1989-1997. Cancer Causes Control 15(4):331-339.

Von Behren J, Reynolds P. 2003. Birth characteristics and brain cancers in young children. Int J Epidemiol 32(2):248-256.

Von Behren J, Reynolds P, Gunier RB, Rull RP, Hertz A Urayama KY, et al. 2008. Residential traffic density and childhood leukemia risk. Cancer Epidemiol Biomarkers Prev 17(9):2298-2301.

Weng HH, Tsai SS, Chen CC, Chiu HF, Wu TN, Yang CY. 2008. Childhood leukemia development and correlation with traffic air pollution in Taiwan using nitrogen dioxide as an air pollutant marker. J Toxicol Environ Health A 71(7):434-438.

Weng HH, Tsai SS, Chiu HF, Wu TN, Yang CY. 2009. Childhood leukemia and traffic air pollution in Taiwan: petrol station density as an indicator. J Toxicol Environ Health $\mathrm{A}$ 72(2):83-87.

Wilhelm M, Qian L, Ritz B. 2009. Outdoor air pollution, family and neighborhood environment, and asthma in LA FANS children. Health Place 15(1):25-36.

Wu J, Wilhelm M, Chung J, Ritz B. 2011. Comparing exposure assessment methods for traffic-related air pollution in an adverse pregnancy outcome study. Environ Res 111(5):685-692.

Yeazel MW, Buckley JD, Woods WG, Ruccione K, Robison LL. 1995. History of maternal fetal loss and increased risk of childhood acute leukemia at an early age. A report from the Childrens Cancer Group. Cancer 75(7):1718-1727.

Yoshida M, Yoshida S, Sugawara I, Takeda K. 2002. Maternal exposure to diesel exhaust decreases expression of steroidogenic factor-1 and Muellerian inhibiting substance in the murine fetus. J Health Sci 48(4):317-324.

Yost K, Perkins C, Cohen R, Morris C, Wright W. 2001. Socioeconomic status and breast cancer incidence in California for different race/ethnic groups. Cancer Causes Control 12(8):703-711.

Zhu YF, Hinds WC, Kim S, Shen S, Sioutas C. 2002. Study of ultrafine particles near a major highway with heavy-duty diesel traffic. Atmos Environ 36(27):4323-4335. 